\title{
PENENTUAN WILAYAH-WILAYAH UNGGULAN PENGEMBANGAN TERNAK BESAR DI PROVINSI NUSA TENGGARA TIMUR
}

\section{DETERMINATION OF THE CENTRAL AREAS FOR THE DEVELOPMENT OF LARGE LIVESTOCK IN THE EAST NUSA TENGGARA PROVINCE}

\author{
Achmad Firman ${ }^{1 *}$, Obed Haba Nono ${ }^{2}$ \\ ${ }^{1}$ Departemen Sosial dan Ekonomi Pembangunan Peternakan, Fakultas Peternakan, \\ Universitas Padjadjaran, Jl. Raya Bandung Sumedang Km 21, Jatinangor Sumedang \\ ${ }^{2}$ Fakultas Peternakan Universitas Nusa Cendnana, Jl. Adisucipto, Penfui-Kupang, \\ Nusa Tenggara Barat \\ *Email: ahmadpedum@yahoo.com \\ (Diterima 23-07-2019; Disetujui 30-07-2019)
}

\begin{abstract}
ABSTRAK
Penelitian ini memiliki tujuan untuk menentukan wilayah-wilayah unggulan pengembangan ternak besar di Provinsi Nusa Tenggara Timur. Penggunaan data sekunder yang berasal dari Badan Pusat Statistik dan Dinas Pertanian Provinsi Nusa Tenggara Timur menjadi sumber data utama untuk kebutuhan analisis pada penelitian ini. Metode analisis yang digunakan pada penelitian ini adalah metode kuantitatif. Hasil penelitian ini menunjukkan bahawa beberapa wilayah yang dapat dijadikan sebagai wilayah unggulan pengembangan ternak besar yang didasarkan pada nilai LQ $>1$ dan SS (+) adalah sebagai berikut: (1) Wilayah sentra pengembangan ternak sapi potong terdapat di Kabupaten Kupang, Timor Tengah Selatan, Belu, Alor, Ende, Rote, Malaka, dan Kota Kupang; (2) Wilayah sentra pengembangan ternak kuda terdapat di Kabupaten Sumba Barat, Lembata, Flores Timur, Sikka, Ngada, Sumba Tengah, Sumba Barat Daya, Manggarai Timur, Sabu Raijua; dan (3) Wilayah sentra pengembangan ternak kerbau terdapat di Kabupaten Sumba Barat, Sumba Timur, Ngada, Rote, Manggarai, Sumba Tengah, Sumba Barat Daya, Nagekeo, Mangarai Timur, Sabua Raijua.
\end{abstract}

Kata Kunci: Sentra, Ternak besar, Sapi Potong, Kuda, Kerbau

\section{DETERMINATION OF LARGE LIVESTOCK DEVELOPMENT CENTRE IN EAST NUSA TENGGARA PROVINCE}

\begin{abstract}
This study aims to determine the central areas for the development of large livestock in the East Nusa Tenggara Province. The data used in this study are secondary data obtained from the Central Statistics Agency and the Agriculture Service of East Nusa Tenggara Province. The analytical method used in this study is a quantitative method. The results of this study indicate that the areas that can be used as centers for large livestock development are as follows: (1) the development of cattle livestock is found in Kupang, Timor Tengah Selatan, Belu, Alor, Ende, Rote, Malaka, and Kupang city (2) Development of horse is found in Sumba Barat, Lembata, Flores Timur, Sikka, Ngada, Sumba Tengah, Sumba Barat Daya, Manggarai Timur, Sabu Raijua; and (3) Development of buffalo is found in Sumba Barat, Sumba Timur, Ngada, Rote, Manggarai, Sumba Tengah, Sumba Barat Daya, nagekeo, Mangarai Timur, Sabua Raijua.
\end{abstract}

Keywords: Central, Large Livestock, Cattle, Horse, Buffalo 


\section{PENDAHULUAN}

Nusa Tenggara Timur (NTT) merupakan provinsi yang berbatasan langsung dengan negara Timor Leste (yang sebelumnya bagian dari negara Republik Indonesia). Provinsi ini memiliki kekhususan dan keunikan karena terdiri atas banyak pulau dengan variasi geografisnya. Namun demikian, hampir di seluruh kabupaten/kota di Provinsi NTT, sektor pertanian mendominasi dibandingkan dengan sektor lainnya (Basuno, 2004). Kontribusi pendapatan sektor pertanian mampu mencapai 28\% terhadap PDRB Provinsi NTT dan serapan tenaga kerja di sektor ini mencapai 55\% (BPS Provinsi NTT, 2019).

Sub sektor peternakan merupakan salah satu subsektor pertanian yang memiliki peranan penting di dalam pembangunan Provinsi NTT. Salah satu misi dari pembangunan Provinsi NTT adalah provinsi ternak. Ternak bagi masyarakat NTT berfungsi sebagai tabungan, mahar perkawinan, sumbangan untuk adat, dan kegiatan religi. Oleh karena itu, pengembangan peternakan menjadi salah satu sasaran pembangunan di NTT.

Salah satu komoditas ternak yang banyak dikembangkan oleh masyarakat adalah sapi, kerbau, dan kuda. Kriteria bagi ternak tersebut adalah dikategorikan sebagai ternak besar. Semua jenis ternak besar dan kecil tersebut sebagai ternak yang paling dominan dipelihara oleh masyarakat pertanian di NTT. Ternak sapi merupakan ternak yang secara turun temurun sudah dipelihara oleh masyarakat pertanian di NTT. Ternak sapi merupakan ternak pemasok kebutuhan daging sapi bagi masyarakat Indonesia (Ilham, 2001). Provinsi NTT sudah sejak lama dijuluki sebagai lumbung bagi ternak sapi potong (Sukada dkk., 2016) karena ternak sapi sudah menjadi bagian dari kehidupan masyarakat pertanian. Jenis ternak sapi yang berkembang di NTT adalah sapi Bali Timor, Sapi Sumba Ongole dan Sapi Madura. Demikian juga ternak kerbau di mana ternak ini telah menjadi bagian dari kehidupan masyarakat NTT. Ternak ini memilliki kemampuan mengkonversi makanan yang kurang berkualitas menjadi daging. Oleh karena wilayah NTT lebih cenderung banyak musim keringnya, maka ketersediaan hijauan menjadi salah satu kendala. Akan tetapi, kerbau memiliki kemampuan untuk mengkonversi hijauan berkualitas rendah. Kuda merupakan bagian dari kehidupan sebagian masyarakat NTT. Kuda-kuda dari provinsi ini telah dikenal di Indonesia. Jenis-jenis kuda yang berkembang adalah Kuda Sandalwood (P. Sumba), Kuda Flores (P. Flores), Kuda 
Timor (P. Timor namun keberadaannya hampir punah), dan Kuda Sabu (P. Sabu). Kuda Sandelwood merupakan sumber daya genetik (SDG) rumpun kuda lokal Indonesia yang dikembangkan di Provinsi Nusa Tenggara Timur (NTT) dengan wilayah sebaran asli geografis berada di Pulau Sumba (Ditjennak, 2014). Kuda ini telah lama berkembang di Pulau Sumba dan menjadi simbol kehidupan masyarakat Sumba baik secara ekonomi, sosial dan budaya, sarana transportasi, sumber protein hewani, pertandingan ketangkasan, dan simbol kebudayaan tertinggi masyarakat (Randu, 2018). Dengan demikian, ternak kuda sudah menjadi bagian yang tidak dapat dipisahkan dari kehidupan dan budaya masyarakat NTT.

Berdasarkan data BPS Provinsi NTT, perkembangan populasi ternak besar, yaitu sapi, kerbau, dan kuda sebanyak 1.007.608 ekor; 162.658 ekor, dan 112.589 ekor pada tahun 2017 (BPS NTT, 2018). Ternak sapi mendominasi populasi ternak besar di NTT. Populasi ternak sapi tersebar merata dibandingkan dengan ternak kerbau. Populasi ternak sapi terkonsentrasi di Kabupaten Sumba, Kupang, dan Timor Tengah Selatan.

Populasi ternak kuda juga tersebar merata di seluruh kabupaten/kota di provinsi ini. Ternak kuda menempati urutan ke tiga terbanyak populasinya di NTT. Populasi ternak kuda terbanyak terkonsentrasi di wilayah Kabupaten Sumba Timur dan Sumba Tengah. Adapun ternak kerbau, walaupun tidak tersebar merata di provinsi ini, namun populasi ternak kerbau menjadi terbanyak ke dua di NTT. Konsentrasi wilayah pengembangan ternak kerbau didasarkan pada jumlah populasinya berada di wilayah Kabupaten Sumba Timur dan Manggarai Barat.

Permasalahan yang sering dihadapi pada perencanaan pembangunan adalah sektor/komoditas mana yang akan dijadikan unggulan di suatu wilayah. Hal inilah yang menjadi fokus dari perencanaan wilayah. Oleh karena itu, tujuan dari penelitian ini adalah untuk menentukan ternak besar yang menjadi unggulan di wilayah-wilayah di NTT yang dapat dijadikan sebagai wilayah pengembangan ternak besar. Penelitian ini menggunakan tiga pendekatan analisis, yaitu analisis Location Quotien, Shift Share, dan Tipologi Klasen. Dengan ketiga analisis tersebut dapat dipetakan wilayahwilayah mana yang menjadi unggulan bagi ternak besar di Provinsi NTT.

\section{Analisis Location Quotient (LQ)} adalah salah satu pendekatan yang umum digunakan dalam model ekonomi basis (Sapriadi dan Hasbullah, 2015). Ekonomi unggulan memiliki peranan penting 
sebagai penggerak utama (primer mover) pertumbuhan wilayah karena berhubungan langsung dengan permintaan akan barang dan jasa dari luar daerah (Adisasmita, 2005; Arsyad, 2005).

Analisis Shift Share (SS) digunakan untuk mengetahui perubahan dan pergeseran sektor pada perekonomian wilayah. Analisis ini mengasumsikan bahwa adanya perubahan produksi ataupun tenaga kerja pada suatu wilayah dibagi ke dalam tiga hal, yaitu pertumbuhan ekonomi, pengaruh pergeseran proporsional, dan pergeseran diferensial atau keunggulan kompetitif yang semuanya dibandingkan antara wilayah dengan wilayah dengan perekonomian yang lebih besar (Adisasmita, 2005; Arsyad, 2005).

Analisis Tipologi Klassen merupakan salah satu alat analisis ekonomi regional yang menggabungkan dua analisis sebelumnya, yaitu LQ dan SS. Dengan dua pendekatan tersebut, Klassen membaginya menjadi 4 kuadran, yaitu sektor yang maju dan tumbuh cepat (Kuadran I); sektor yang maju tapi tertekan (Kuadran II); sektor potensial (Kuadran III); dan sektor relatif tertinggal (Kuadran IV) (Widodo, 2006 dalam Rahayu, 2010).

Berdasarkan ke tiga pendekatan analisis tersebut dapat ditentukan ternak besar unggulan yang dapat dikembangkan di suatu wilayah di NTT. Hasil analisis ini dapat memberikan gambaran wilayah mana yang dapat dijadikan sebagai sentra pengembangan ternak besar. Penelitian ini belum pernah ada yang meneliti sebelumnya sehingga penelitian bisa menjadi rujukan bagi Pemerintah Daerah NTT dalam pengembangan ternak besar.

\section{METODE}

Objek penelitian yang digunakan dalam penelitian ini adalah data-data yang terkait dengan penentuan ternak besar unggulan di Provinsi Nusa Tenggara Timur.

Metode yang digunakan dalam penelitian ini adalah metode kuantitatif yang hasil analisisnya dideskripsikan untuk menjelaskan temuan dari data yang dianalisis.

Data yang dikumpulkan adalah data sekunder yang diperoleh dari Badan Pusat Statistik dan Dinas Pertanian Provinsi Nusa Tenggara Timur yang berkaitan dengan penelitian ini.

Metode analisis yang digunakan dalam penelitian ini adalah sebagai berikut:

a. Analisis Location Quotient (LQ) diformulasikan sebagai berikut:

$$
\text { LQ }=\frac{\text { Vi/Vt }}{\mathbf{Y i} / \mathbf{Y t}}
$$


Dimana:

Vi : populasi ternak besar i pada tingkat kabupaten/kota

$\mathrm{Vt}$ : total populasi ternak besar di tingkat provinsi

Yi : populasi ternak besar i di tingkat nasional

Yt : total populasi ternak besar di tingkat nasional

Keterangan (Silaban, dkk., 2015):

- Nilai LQ $=0$; ternak besar i sama dengan wilayah lainnya

- Nilai LQ > 1; ternak besar i merupakan ternak unggulan wilayah

- Nilai LQ $<1$; ternak besar i bukan merupakan ternak basis/unggulan wilayah.

b. Analisis Shift Share (SS) diformulasikan sebagai berikut:

$$
\begin{aligned}
& \mathrm{Dij}=\mathrm{Nij}+\mathrm{Mij}+\mathrm{Cij} \\
& \mathrm{Nij}=\mathrm{Eij} \cdot \mathrm{rn} \\
& \mathrm{Mij}=\mathrm{Eij}(\mathrm{rin}-\mathrm{rn}) \\
& \mathrm{Cij}=\mathrm{Eij}(\mathrm{rij}-\mathrm{rin})
\end{aligned}
$$

Keterangan: $\mathrm{i}=$ komoditas ternak besar yang diteliti; $\mathrm{j}=$ variabel wilayah yang diteliti; $\quad$ Dij $=$ Perubahan ternak besar $\mathrm{i}$ di daerah $\mathrm{j} ; \quad \mathrm{Nij}=$ Pertumbuhan ternak besar i di daerah $\mathrm{j}$; Mij = Bauran ternak besar $\mathrm{i}$ di daerah $\mathrm{j}$; $\mathrm{Cij}=$ Keunggulan kompetitif ternak besar i di daerah j; Eij $=$ total populasi ternak besar i di daerah $\mathrm{j} ;$ rij = laju pertumbuhan ternak besar i di daerah $\mathrm{j}$; rin $=$ laju pertumbuhan ternak besar $\mathrm{i}$ di daerah $\mathrm{n}$; $\mathrm{rn}=$ laju pertumbuhan populasi ternak besar di

daerah n. Hasil dari analisis SS terbagi atas dua, yaitu SS (+) berarti ternak potensial di suatu wilayah, sedangkan SS (-) berarti ternak tidak potensial di suatu wilayah.

c. Tipologi Klassen sebagai alat analisis regional yang merupakan gabungan dari LQ dan SS yang disusun dalam suatu kuadran sebagai berikut:

Tabel 1. Klasifikasi Ternak Besar di NTT Menurut Tipologi Klassen

\begin{tabular}{c|c}
\hline $\begin{array}{c}\text { Kuadran II } \\
\text { Ternak besar (i) maju } \\
\text { tapi tertekan }\end{array}$ & $\begin{array}{c}\text { Kuadran I } \\
\text { Ternak besar (i) maju } \\
\text { dan tumbuh pesat } \\
(\mathrm{LQ}<1 ; \mathrm{SS}+)\end{array}$ \\
\hline Kuadran IV $>1 ; \mathrm{SS}+)$ \\
Ternak besar (i) & Kuadran III \\
tertinggal & Ternak besar (i) \\
$(\mathrm{LQ}<1 ; \mathrm{SS}-)$ & potensial \\
\hline
\end{tabular}

Semua analisis di atas harus diseragamkan terlebih dahulu. Satuan unit ternak merupakan satuan penyeragaman dari ekor ke satuan ternak (animal unit). satuan dari ternak. Oleh karena itu, untuk penyeragaman ukuran ternak digunakan animal unit (satuan ternak) dengan ukuran sebagai berikut: satuan ternak (ST) untuk 1 ekor sapi potong sama dengan 0,8 ST (rataan dari sapi induk, dara, dan pedet), sedangkan untuk 1 ekor kuda atau kerbau sama dengan 0,7 ST (rataan dari kuda/kerbau induk, dara, dan anak kuda/kerbau). 


\section{HASIL DAN PEMBAHASAN}

\section{Gambaran Umum}

Populasi ternak besar dapat dilihat pada Gambar 1. Pada gambar tersebut dapat dilihat bahwa seluruh populasi ternak besar mengalami peningkatan. Peningkatan yang signifikan terjadi pada ternak sapi. Pada tahun 2004, populasi ternak sapi hanya sebanyak lebih dari 552 ribu ekor, akan tetapi pada tahun 2017 menjadi lebih dari satu juta ekor. Ini berarti peningkatan populasi sapi selama 13 tahun hampir 500 ribu ekor.

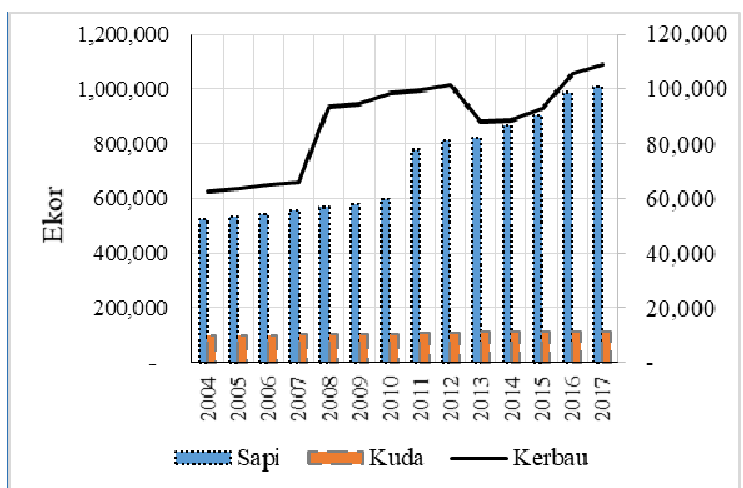

Gambar 1. Perkembangan Populasi Ternak besar di Provinsi NTT

Adapun ternak kuda yang merupakan komoditas andalan bagi NTT, populasinya tidak mengalami peningkatan yang signifikan atau hampir dikatakan statis. Hal ini seharusnya menjadi perhatian pemerintah setempat atas kondisi ini karena ternak kuda merupakan icon bagi Provinsi Nusa Tenggara Timur. Adapun ternak kerbau mengalami peningkatan populasi dari tahun 2004 sampai dengan 2017, yaitu dari 62 ribu ekor menjadi lebih dari 100 ribu ekor.

Penentuan wilayah unggulan ternak sapi didekati dengan tiga pendekatan analisis, yaitu analisis LQ, SS, dan Tipologi Klasen. Ketiga analisis ini digunakan untuk menentukan wilayah unggulan ternak sapi potong, kuda, dan kerbau. Selanjutnya, hasil-hasil penentuan wilayah tersebut diuraikan di bawah ini.

\section{Penentuan Wialayah Unggulan Ternak Sapi Potong}

Analisis LQ yang digunakan untuk menentukan komoditas basis, khususnya sapi potong, dapat dilihat pada Tabel 2 .

Tabel 2. Hasil Analisis LQ Ternak Sapi Potong

\begin{tabular}{l|c|c}
\multicolumn{1}{c|}{ Kabupaten/Kota } & LQ & Keterangan \\
\hline Kupang & 1,19 & Basis \\
Timor Tengah Selatan & 1,23 & Basis \\
Timor Tengah Utara & 1.22 & Basis \\
Belu & 1.19 & Basis \\
Alor & 1.22 & Basis \\
Ende & 1.09 & Basis \\
Malaka & 1.22 & Basis \\
Kota Kupang & 1,22 & Basis \\
\hline
\end{tabular}

Berdasarkan data pada Tabel 2 terdapat 7 kabupaten dan 1 kota yang memiliki nilai LQ lebih besar dari 1. Artinya, ternak sapi potong pada ke 8 wilayah tersebut memiliki keunggulan komparatif dibandingkan ternak besar lainnya. Nilai LQ yang terbesar pada wilayah-wilayah unggulan tersebut adalah Kabupaten Timor Tengah Selatan, 
sedangkan yang terkecil nilai LQnya adalah Kabupaten Ende.

Analisis SS digunakan untuk menentukan keunggulan kompetitif pada ternak sapi potong yang ada di wilayah tersebut. Hasil analisis dapat dilihat pada Tabel 3.

Tabel 3. Hasil Analisis SS Ternak Sapi Potong

\begin{tabular}{lcc}
\hline \multicolumn{1}{c}{ Kabupaten/Kota } & SS & Keterangan \\
\hline Sumba Barat & 0,12 & + \\
Kupang & 0,02 & + \\
Timor Tengah Selatan & 0,03 & + \\
Belu & 0,18 & + \\
Alor & 0,02 & + \\
Ende & 0,03 & + \\
Ngada & 0,09 & + \\
Manggarai & 0,02 & + \\
Rote Ndao & 0,09 & + \\
Manggarai Barat & 0,41 & + \\
Sumba Tengah & 0,02 & + \\
Sumba Barat Daya & 0,09 & + \\
Manggarai Timur & 0,09 & + \\
Sabu Raijua & 0,43 & + \\
Malaka & 0,03 & + \\
Kota Kupang & 0,06 & + \\
\hline
\end{tabular}

Berdasarkan data pada Tabel 3 tersebut terdapat 16 wilayah yang memiliki nilai SS positif. Artinya, ternak sapi potong pada ke 16 wilayah tersebut memiliki keunggulan kompetitif dibandingkan ternak besar lainnya. Nilai SS yang terbesar pada wilayah-wilayah unggulan tersebut adalah Kabupaten Manggarai Barat dan Sabu Raijua. Oleh karena itu, kedua kabupaten ini memiliki keunggulan kompetitif untuk ternak sapi potong dibandingkan dengan kabupaten lainnya yang memiliki nilai positif.
Berdasarkan hasil analisis di atas, maka untuk menentukan wilayah mana yang memiliki keunggulan komparatif dan kompetitif di analisis dengan menggunakan Tipologi Klasen. Analisis Tipologi Klasen memadukan hasil dari LQ dan SS.

Hasil analisis Tipologi Klassen memperlihatkan wilayah-wilayah unggulan untuk ternak sapi potong, seperti pada Tabel 4.

Tabel 4. Hasil Tipologi Klassen Ternak Sapi Potong

\begin{tabular}{|c|c|c|}
\hline $\begin{array}{c}\text { Sapi } \\
\text { Potong }\end{array}$ & $\mathbf{L Q}>\mathbf{1}$ & $\mathbf{L Q}<\mathbf{1}$ \\
\hline SS+ & $\begin{array}{c}\text { Kupang, Timor } \\
\text { Tengah Selatan, } \\
\text { Belu, Alor, Ende, } \\
\text { Rote, Malaka, Kota } \\
\text { Kupang }\end{array}$ & $\begin{array}{l}\text { Sumba Barat, } \\
\text { Ngada, Manggarai, } \\
\text { Manggarai Barat, } \\
\text { Sumba Tengah, } \\
\text { Sumba Barat Daya }\end{array}$ \\
\hline SS- & $\begin{array}{c}\text { Timor tengah } \\
\text { Utara, Manggarai } \\
\text { Timur }\end{array}$ & $\begin{array}{l}\text { Sumba Timur, } \\
\text { Lembata, Flores } \\
\text { timur, Sikka, } \\
\text { Nagekeo, Sabu } \\
\text { Raijua }\end{array}$ \\
\hline
\end{tabular}

Ket: daerah yang diarsir adalah wilayah unggulan ternak sapi potong

Berdasarkan Tabel 4 dapat ditentukan wilayah-wilayah sentra pengembangan sapi potong di Provinsi Nusa Tenggara Timur, yaitu: Kabupaten Kupang, Timor Tengah Selatan, Belu, Alor, Ende, Rote, Malaka, Kota Kupang. Wilayah-wilayah tersebut dapat direkomendasikan sebagai wilayah yang memiliki keunggulan komparatif dan kompetitif untuk pengembangan sapi potong. 
Penentuan Wialayah Unggulan Ternak Kuda

Analisis LQ yang digunakan untuk menentukan komoditas basis, khususnya kuda, dapat dilihat pada Tabel 5.

Tabel 5. Hasil Analisis LQ Ternak Kuda

\begin{tabular}{l|c|c}
\hline \multicolumn{1}{c|}{ Kabupaten/Kota } & LQ & Keterangan \\
\hline Sumba Barat & 3,61 & Basis \\
Sumba Timur & 3,21 & Basis \\
Lembata & 3,40 & Basis \\
Flores Timur & 5,60 & Basis \\
Sikka & 1,95 & Basis \\
Ngada & 1,26 & Basis \\
Sumba Tengah & 4,63 & Basis \\
Sumba Barat Daya & 3,08 & Basis \\
Manggarai Timur & 2,42 & Basis \\
Sabu Raijua & 3,98 & Basis \\
\hline
\end{tabular}

Berdasarkan Tabel 5 tersebut terdapat 10 kabupaten yang memiliki nilai LQ lebih besar dari 1. Artinya, ternak kuda pada ke 10 wilayah tersebut memiliki keunggulan komparatif dibandingkan ternak besar lainnya. Nilai LQ yang terbesar pada wilayah-wilayah unggulan tersebut adalah Kabupaten Flores Timur dan Sumba Tengah, sedangkan untuk kabupaten dengan nilai LQ terendah pada wilayah unggulan tersebut terdapat pada wilayah Ngada.

Analisis SS digunakan untuk menentukan keunggulan kompetitif pada ternak kuda yang ada di wilayah tersebut. Hasil analisis dapat dilihat pada Tabel 6 . Berdasarkan Tabel 6 tersebut terdapat 13 kabupaten yang memiliki nilai SS positif. Artinya, ternak kuda pada ke 13 kabupaten tersebut memiliki keunggulan kompetitif dibandingkan ternak besar lainnya. Nilai SS yang terbesar pada wilayah-wilayah unggulan tersebut adalah Kabupaten Sabu Raijua, sedangkan yang terendah adalah Kota Kupang. Oleh karena itu, ketiga kabupaten ini memiliki keunggulan kompetitif untuk ternak kuda dibandingkan dengan kabupaten lainnya yang memiliki SS positif. Nilai SS yang besar ini dapat mengindikasikan bahwa wilayah tersebut memiliki keunggulan yang sangat kompetitif untuk ternak kuda. Akan tetapi, walaupun wilayah-wilayah yang memiliki nilai SS (+), belum tentu dapat dijadikan sebagai wilayah sentra pengembangan kuda karena harus dianalisis lagi dengan analisis Tipologi Klasen.

\begin{tabular}{lcc}
\multicolumn{3}{c}{ Tabel 6. Hasil Analisis SS Ternak Kuda } \\
\hline \multicolumn{1}{c}{ Kabupaten/Kota } & SS & Keterangan \\
\hline Sumba Barat & 0,05 & + \\
Alor & 0,02 & + \\
Lembata & 0,02 & + \\
Flores Timur & 0,02 & + \\
Sikka & 0,02 & + \\
Ende & 0,02 & + \\
Ngada & 0,02 & + \\
Rote Ndao & 0,02 & + \\
Sumba Tengah & 0,02 & + \\
Sumba Barat Daya & 0,02 & + \\
Manggarai Timur & 0,02 & + \\
Sabu Raijua & 2,75 & + \\
Kota Kupang & 0,01 & + \\
\hline
\end{tabular}

Hasil analisis Tipologi Klassen memperlihatkan wilayah-wilayah unggulan untuk ternak kuda, seperti pada Tabel 7. Berdasarkan Tabel 7 tersebut dapat ditentukan wilayah-wilayah sentra pengembangan kuda yang didasarkan pada 
nilai LQ $>1$ dan SS (+), yaitu: Kabupaten

Sumba Barat, Sumba Timur, Sikka, Ngada, Sumba Tengah, Sumba Barat Daya, Manggarai Timur, Sabu Raijua. Wilayahwilayah tersebut dapat direkomendasikan sebagai wilayah pengembangan kuda karena memiliki keunggulan dari sisi komparatif maupun sisi kompetitif.

Tabel 7. Hasil Analisis Tipologi Klassen Ternak Kuda

\begin{tabular}{|c|c|c|}
\hline Kuda & $\mathbf{L Q}>\mathbf{1}$ & $\mathbf{L Q}<\mathbf{1}$ \\
\hline SS+ & $\begin{array}{c}\text { Sumba Barat, } \\
\text { Lembata, Flores } \\
\text { Timur, Sikka, } \\
\text { Ngada, Sumba } \\
\text { Tengah, Sumba } \\
\text { Barat Daya, } \\
\text { Manggarai Timur, } \\
\text { Sabu Raijua }\end{array}$ & Ende, Kota Kupang \\
\hline SS- & $\begin{array}{c}\text { Sumba Timur, } \\
\text { Manggarai Barat, } \\
\text { Nagekeo, } \\
\text { Manggarai, Malaka }\end{array}$ & $\begin{array}{c}\text { Kupang, Timor } \\
\text { Tengah Selatan, } \\
\text { Timor Tengah Utara, } \\
\text { Belu, Alor }\end{array}$ \\
\hline
\end{tabular}

\section{Penentuan Wialayah Unggulan Ternak Kerbau}

Analisis LQ yang digunakan untuk menentukan komoditas basis, khususnya kerbau, dapat dilihat pada Tabel 8 . Berdasarkan Tabel 8 tersebut terdapat 11 kabupaten yang memiliki nilai LQ lebih besar dari 1. Artinya, ternak kerbau pada ke 11 wilayah tersebut memiliki keunggulan komparatif dibandingkan ternak besar lainnya. Nilai LQ yang terbesar pada wilayah-wilayah unggulan tersebut adalah Kabupaten Sumba Barat dan Sumba Barat
Daya, sedangkan untuk kabupaten dengan nilai LQ terendah pada wilayah unggulan tersebut terdapat pada wilayah Rote Ndao. Namun demikian, bukan berarti wilayah yang memiliki LQ $>1$ tersebut dapat dijadikan wilayah unggulan, namun harus diuji oleh dua analisis lagi.

Tabel 8. Hasil Analisis LQ Ternak Kerbau

\begin{tabular}{l|c|c}
\hline \multicolumn{1}{c|}{ Kabupaten/Kota } & LQ & Keterangan \\
\hline Sumba Barat & 5,49 & Basis \\
Sumba Timur & 2,60 & Basis \\
Ngada & 1,83 & Basis \\
Manggarai & 1,81 & Basis \\
Rote Ndao & 1,15 & Basis \\
Manggarai Barat & 4,43 & Basis \\
Sumba Tengah & 2,79 & Basis \\
Sumba Barat Daya & 5,33 & Basis \\
Nagekeo & 1,28 & Basis \\
Manggarai Timur & 2,67 & Basis \\
Sabu Raijua & 3,76 & Basis \\
\hline
\end{tabular}

Analisis SS digunakan untuk menentukan keunggulan kompetitif pada ternak kerbau yang ada di wilayah tersebut. Hasil analisis dapat dilihat pada Tabel 9.

Tabel 9. Hasil Analisis SS Ternak Kerbau

\begin{tabular}{lcc}
\hline \multicolumn{1}{c}{ Kabupaten/Kota } & SS & Keterangan \\
\hline Sumba Barat & 0,04 & + \\
Sumba Timur & 0,03 & + \\
Kupang & 0,02 & + \\
Timor Tengah Selatan & 0,01 & + \\
Timor Tengah Utara & 0,88 & + \\
Sika & 0,02 & + \\
Ende & 0,01 & + \\
Ngada & 0,02 & + \\
Manggarai & 0,02 & + \\
Rote Ndao & 0,02 & + \\
Sumba Tengah & 0,02 & + \\
Sumba Barat Daya & 0,11 & + \\
Nagekeo & 0,02 & + \\
Manggarai Timur & 0,02 & + \\
Sabu Rajua & 0,34 & + \\
\hline
\end{tabular}

Berdasarkan Tabel 9 tersebut terdapat 15 kabupaten yang memiliki nilai SS 
positif. Artinya, ternak kerbau pada ke 15 kabupaten tersebut memiliki keunggulan kompetitif dibandingkan ternak besar lainnya. Nilai SS yang terbesar pada wilayah-wilayah unggulan tersebut adalah Kabupaten Timor Tengah Utara dan Sabu Raijua, dan Sumba Barat Daya. Oleh karena itu, ketiga kabupaten ini memiliki keunggulan kompetitif untuk ternak kerbau dibandingkan dengan kabupaten lainnya yang memiliki SS positif. Nilai SS yang besar ini dapat mengindikasikan bahwa wilayah tersebut memiliki keunggulan yang sangat kompetitif untuk ternak kerbau, namun belum tentu dapat dijadikan wilayah pengembangan.

Hasil analisis Tipologi Klassen memperlihatkan wilayah-wilayah unggulan untuk ternak kerbau, seperti pada Tabel 10.

Tabel 10. Hasil Analisis Tipologi Klassen Ternak Kerbau

\begin{tabular}{ccc}
\hline Kerbau & LQ $>\mathbf{1}$ & $\mathbf{L Q}<\mathbf{1}$ \\
\hline \multirow{4}{*}{ SS+ } & Sumba Barat, Sumba & Kupang, Timur \\
& Timur, Ngada, Rote, & Tengah Selatan, \\
& Manggarai, Sumba & Timur Tengah \\
& Tengah, Sumba Barat & Utara, Sikka, \\
& Daya, nagekeo, & Ende \\
& Mangarai Timur, Sabua & \\
\hline & Raijua & \\
\hline
\end{tabular}

SS- $\quad$ Manggarai Barat Belu

Ket: daerah yang diarsih adalah wilayah unggulan ternak kerbau

Berdasarkan Tabel 10 tersebut dapat ditentukan wilayah-wilayah sentra pengembangan kuda yang didasarkan pada nilai LQ $>1$ dan SS (+), yaitu: Kabupaten Sumba Barat, Sumba Timur, Sikka, Ngada, Sumba Tengah, Sumba Barat Daya, Manggarai Timur, Sabu Raijua. Wilayahwilayah tersebut dapat direkomendasikan sebagai wilayah pengembangan kuda karena memiliki keunggulan dari sisi komparatif maupun sisi kompetitif.

\section{KESIMPULAN}

Berdasar hasil uraian di atas dapat disimpulkan bahwa wilayah-wilayah yang dapat dijadikan sentra pengembangan ternak besar adalah sebagai berikut:

1. Wilayah sentra pengembangan ternak sapi potong terdapat di Kabupaten Kupang, Timor Tengah Selatan, Belu, Alor, Ende, Rote, Malaka, dan Kota Kupang

2. Wilayah sentra pengembangan ternak Kuda terdapat di Kabupaten Sumba Barat, Lembata, Flores Timur, Sikka, Ngada, Sumba Tengah, Sumba Barat Daya, Manggarai Timur, Sabu Raijua.

3. Wilayah sentra pengembangan ternak kerbau terdapat di Kabupaten Sumba Barat, Sumba Timur, Ngada, Rote, Manggarai, Sumba Tengah, Sumba Barat Daya, nagekeo, Mangarai Timur, Sabua Raijua. 


\section{DAFTAR PUSTAKA}

Adisasmita, R. 2005. Dasar-Dasar Ekonomi Wilayah. Yogyakarta: Graha Ilmu.

Arsyad, L, 2005. Pengantar Perencanaan Pembangunan Ekonomi Daerah. Edisi Kedua. Yogyakarta: BPFE.

Basuna, E. 2004. Mengembalikan Status Wilayah Nusa Tenggara Sebagai Gudang Ternak. AKP 2(4): 354-368.

Ditjennak. 2014. Keputusan Menteri Pertanian Republik Indonesia Nomor 426/Kpts/SR.120/3/2014 Tentang Penetapan Rumpun Kuda Sandel. http://bibit.ditjennak.pertanian.go. $\mathrm{id} /$ sites/default/files/Kuda\%20Sandel. pdf. Diakses tanggal 22 Juli 2019.

Ilham, N. 2001. Analisis Penawaran dan Permintaan Daging Sapi di Indonesia. Prosiding Seminar Nasional Teknologi Peternakan dan Veteriner, Pusat Penelitian dan Pengembangan Peternakan, Bogor: 385-403.

Randu, M. D. S. dan B. Hartono. 2018. Keragaan Pengembangan Kuda Sandelwood di Wilayah Pasola Kabupaten Sumba Barat Daya. Jurnal Sains Peternakan 16(2): 54-62.
Rahayu, E.S. 2010. Aplikasi Tipologi Klassen Pada Strategi Pengembangan Sub Sektor Pertanian Tanaman Pangan di Kabupaten Boyolali. Journal of Rural and Development 1(2): 105-121.

Sapriadi dan Hasbullah. 2015. Analisis Penentuan Sektor Unggulan Perekonomian Kabupaten Bulukumba. Jurnal Iqtisaduna 1(1): 71-86.

Silaban L.H, Edwina S., Eliza. 2015. Analisis Sektor Basis dan Perkembangan Sektor Pertanian di Kabupaten Indragiri Hilir Provinsi Riau Tahun 2008-2012. Jom Faperta 2(1). Jurusan Agribisnis Fakultas Pertanian Universitas Riau.

Sudkada, I K., I W. Subrata, dan I G. Suarta. 2016. Potensi Ternak Sapi Potong, Sapi Perah dan Kerbau Sebagai Penghasil Daging di Kabupaten Nusa Tenggara Timur. Majalah Ilmiah Peternakan 19(3): 101-104. 